\title{
Place zabaw w przestrzeni publicznej
}

\section{Bartłomiej Kwiatkowski}

\author{
Wydziat Budownictwa i Architektury, Politechnika Lubelska
}

Projektowanie placów zabaw oraz możliwości ich realizacji zmieniły się na przestrzeni kilkudziesięciu lat w sposób umożliwiający spełnienie najśmielszych pomysłów projektantów, bez ograniczeń materiałowych, konstrukcyjnych i pod względem bezpieczeństwa.

Wśród przykładów typowych, katalogowych placów zabaw, które są projektowane poprzez usytuowanie na wybranym terenie elementów zabawowych dla dzieci (zjeżdżalni, huśtawek, drabinek wspinaczkowych itp., itd.) w sposób przewidziany przez producenta spełniając wymogi odległości elementów względem siebie oraz odległości względem granic terenu, coraz więcej powstaje realizacji placów zabaw zaprojektowanych w unikalny sposób. Przykłady takich projektów szczególnie są warte uwagi ze względu na fakt, że ich oryginalność oraz nietypowość wpływają na wiele czynników bezpośrednio lub pośrednio z nimi związanych. Jednym z takich czynników jest wpływ na przestrzeń publiczną w otoczeniu placu, który poprzez swoją formę staję się ikoną miejsca a nawet może stać się jego logiem bądź wizytówką. Przykładem takiego miejsca, które powstało w latach 60-tych, jest plac zabaw z rakieta w osiedlu LSM w Lublinie. Fala zainteresowania po locie Jurija Gagarina w kosmos spowodowała impuls do budowy zjeżdżalni w kształcie rakiety kosmicznej. Już w połowie XX wieku pojawiały się pomysły na oryginalny projekt małej architektury dla dzieci.

Obecnie możliwości konstrukcyjne i różnorodność materiałowa a także szeroki wachlarz bezpiecznych elementów wyposażenia sprawiają, że projektanci mogą spełniać swoje wizje placów zabaw zamieniając te miejsca w przestrzenie pobudzające wszystkie zmysły u dzieci. Zabawa ${ }^{1}$, w czasie modernizmu sprowadzana była do placów dobrze wyposażonych i specjalnie wydzielonych - obecnie jest oczekiwaną aktywnością w miejskiej przestrzeni. Ingerencje w przestrzeń miejską posiadające w zamyśle zwrócenie uwagi przechodnia lub zatrzymanie go $w$ danym miejscu poprzez wykreowanie pretekstu będącego niejednokrotnie związanym z bezpośrednią interakcją z przechodniem. Jednym z takich przykładów są mobilne meble uliczne, powstałe w 2010 roku, których zasadą jest zespół ruchomych platform mogących stać się stolikami lub ławkami po wysunięcia się z poziomu chodnika. Dodatkowym elementem ich mobilności jest to, że wysunięcie możliwe jest przy współpracy kilku osób co wpływa korzystnie na współpracę i integrację społeczną.

\section{Wymogi prawne oraz specyficzne wymagania projektowe placów zabaw}

Ogólne wymogi prawne odnoszące się bezpośrednio do sytuowania oraz projektowania placów zabaw znajdują się w Rozporządzeniu Ministra Infrastruktury i Rozwoju w sprawie warunków technicznych, jakim powinny odpowiadać budynki i ich usytuowanie. Szczegółowe informacje dotyczące np.: wymagań bezpieczeństwa, huśtawek, zjeżdżalni, przestrzennych konstrukcji sieciowych lub nawierzchni określają odpowiednie normy PN-EN, zwłaszcza PN-EN 1176 i PN-EN 1177. Warto zwrócić uwagę na jeszcze dwie normy odnoszące się do nadmuchiwanych sprzętów do zabawy oraz dla użytkowników sprzętu rolkowego: PN-EN 14960 i PN-EN 14974. ${ }^{2}$

W ogólnych uwarunkowaniach przy projektowaniu placów zabaw przede wszystkim należy określić grupę użytkowników. Jeżeli są to dzieci zdrowe, należy wtedy uwzględnić prawidłowe strefowanie przestrzeni w zależności od wieku użytkowników. Strefa dla najmłodszych (do lat 3) powinna być wydzielona w taki sposób aby uniemożliwić dzieciom korzystanie z zabawek dla starszych, z których mogą upaść z wysokości powyżej $1 \mathrm{~m}$ a także aby nie wywoływać kolizji pomiędzy dziećmi w różnym wieku. Takie strefowanie jest również potrzebne z uwagi na rodzaje zabawek z podziałem na wiek, starsze dzieci mogą przyczynić się nieświadomie do 
dewastacji zabawek dla maluchów. Jeżeli wśród grupy użytkowników będą występować dzieci z niepełnosprawnością lub całkowicie plac będzie dedykowany takim grupom rolą projektanta jest sprecyzowanie dokładnych wymagań przyszłych użytkowników, ich ograniczeń ze względu na stopień i charakter niepełnosprawności oraz możliwości korzystania z urządzeń zabawowych. Jest to rodzaj projektowania spersonalizowanego, w którym projektowana przestrzeń jest dogłębnie przemyślanym miejscem, które będzie umożliwiać spędzenie czasu na nie tylko formie zabawy ale i rozwoju, terapii lub rehabilitacji.

Jednym z najważniejszych elementów na placu zabaw jest nawierzchnia. To z jakiego materiału zostanie wykonana wpływa na komfort użytkowników, zwłaszcza na amortyzację upadków z zabawek. Obowiązujące przepisy prawne określają strefy w których nawierzchnia bezpieczna powinna znajdować się pod urządzeniami, na których dzieci mogą bawić się na wysokości powyżej 600 mm oraz wokół urządzeń takich jak huśtawki, karuzele i zjeżdżalnie. Według norm taką nawierzchnią może być nawierzchnia trawiasta aczkolwiek to zależy od klimatu danego regionu - zimą nawierzchnia ta znacznie zmienia swoje właściwości.

Wśród najpopularniejszych nawierzchni stosowanych na placach zabaw są:

- sypka: może być wykonana wiórów drzewnych, kory, rozdrobnionego mechanicznie drewna, żwiru, piasku lub rozdrobnionej gumy - grubość warstwy to minimum $300 \mathrm{~mm}^{3}$

- gumowa: Nawierzchnia bezpieczna, którą można ułożyć z pojedynczych elementów lub wykonać na miejscu (rozdrobniona guma spojona żywicą). Odpowiednie normy określają stopień bezpieczeństwa w zależności od kryterium HIC (Kryterium Urazu Głowy). Jest to materiał o bardzo dużym potencjale projektowym ze względu na możliwości kolorystyczne;

- kratki gumowe łącznie z rosnącą pomiędzy oczkami kratek trawą;

- powierzchnie dywanowe.

Istotne jest aby zapewnić bezpieczeństwo na placu zabaw. Ogólnym warunkiem do spełnienia jest zachowanie odległości 1,5 m dla urządzeń o wysokości do 1,5 m. Urządzenia typu huśtawki posiadają inne wymagania, których sposób obliczenia został sporządzony w odpowiednich normach.

Jednym z elementów tworzącym zarówno tło dla miejsca zabaw jak i będącego dopełnieniem pod względem odbioru miejsca poprzez zmysły dzieci jest roślinność. Szczególnie istotną rolę odgrywa $w^{4}$ projektowaniu spersonalizowanym np.: przestrzeni ogrodów sensorycznych (hortiterapii). Odpowiedni dobór roślinności, odpowiednich drzew, krzewów, kwiatów powoduje wprowadzenie dodatkowych walorów estetycznych i funkcjonalnych szczególnie ważnych dla użytkowników niepełnosprawnych. Na przykładzie ogrodów sensorycznych pozwalających na interakcję z roślinnością poprzez użycie wszystkich zmysłów tj. dotyku faktury elementów roślinnych lub wodnych, zapachu woni kwiatów, smaku owoców lub warzyw i oglądania niezliczonych form oraz kolorów natury można stwierdzić, że odpowiednie użycie gatunków roślinnych może wpłynąć na nasze zmysły, zwłaszcza sprzyja to wyciszeniu i uspokojeniu organizmu. Rośliny, które mogą wprowadzić dodatkowy walor w placu zabaw to np.: zioła, czojsia, topola, czarny bez, kalina pachnąca, powojnik pachnący, klon polny, stokrotka róża pomarszczona, ostrokrzew kolczasty, cis pospolity, jarzębina, bluszcz, rododendron, robinia akacjowa itp.

\section{Przykłady realizacji przestrzeni zabaw}

Wśród najnowszych realizacji placów zabaw warto zwrócić szczególną uwagę na kilka realizacji o unikatowym charakterze. Przykłady te dodatkowo mogą zostać podzielona na trzy grupy:

I. Projekty tematyczne.

II. Projekty powiązane $z$ architekturą krajobrazu.

III. Projekty związane z ćwiczeniami fizycznymi.

Pierwsza grupa projektów opiera się na placach zabaw tematycznych. Są to projekty wykorzystujące jeden przewodni temat, który rozwinięty przejawia się w każdym elemencie przestrzeni. Jednym z przykładów jest Dragon Playground w Berlinie autorstwa Pro Garten Landschaftsarchitektur. Pomysł związany jest z wykorzystaniem 
fantastycznych smoków jako ${ }^{5}$ mśl przewodnia. Tor przeszkód, zjeżdżalnie ora huśtawki utrzymane są w jednolitej, zielonej kolorystyce a nawierzchnia placu to podłoże piaskowe z pojedynczymi większymi kamieniami po których dzieci mogą skakać. Kolejnym przykładem jest The Cargoship in Hoganas w Hoganas Marina autorstwa Monstrum. Ten projekt to w połowie „tonący” okręt z latarnią morską oraz skrzyniami, które przypadkowo ustawiono wokół statku. W tym miejscu również postawiono na nawierzchnię piaszczystą wokół wszystkich elementów. Warto zwrócić uwagę na bardzo dokładne wykonanie w detalu elementów placu. Dbałość o bezpieczeństwo dzieci postawiono na pierwszym miejscu - wszystkie elementy konstrukcyjne typu śruby czy gwoździe w pieczołowity sposób zostały zamaskowane. W podobnej stylistyce został utrzymany The Bermuda Traingle w Kopenhadze autorstwa również pracowni Monstrum. Wartym uwagi jest projekt The Other Star Playground DossestraSe w Berlinie autorstwa birke - Zimmermann landschaftsarchitekten. Jest to o tyle niezwykły projekt, że ukazuje fragment układu słonecznego, planety, drogę mleczną w skali odpowiedniej dla dzieci z mniejszym wieku. Tutaj również podobnie jak w ww. projektach największą powierzchnię zajmuje nawierzchnia piaszczysta. Drogę mleczną wykonano z asfaltu malując na nim białe gwiazdy, kolorem przewodnim jest pomarańczowy. Całość wykonano z wielką dbałością o detal.

Następną grupą projektów, jest grupa powiązana z architekturą krajobrazu. Przykładem takiej przestrzeni jest Dry Cleaning II: "Fall into the Moon" w Grand Metis, Quebec autorstwa AMMA architecture de paysage. W projekcie wydzielono przestrzenie tematyczny różnych elementów, które użytkownicy mogą wykorzystywać na wiele sposobów, w tym do nauki oraz pod kątem sensorycznym. W jednym z miejsc zastosowano przeskalowane w wielkości liczydła kul z PCV zawieszonych na stalowych cięgnach. W wielu miejscach poza piaszczystymi nawierzchniami możemy odnaleźć nawierzchnie żwirowe, wysypane kawałkami kory, drewniane podesty oraz różne rodzaje nawierzchni trawiastej. Jedną z sensualnych przestrzeni jest pomost drewniany nad którym rozpięto ruszt z drewnianych elementów do których zamocowano delikatne sznurki w kolorze białym. Przestrzenią wymagającą kooperacji oraz współpracy wielu dzieci jest system przekładni, pomp oraz korytek po których spływa woda. Syntetyczny projekt autorstwa ANNABAU Architektur und Landshaft o nazwie Sculptural Playground. Unikatowy w formie plac zabaw oparto na konstrukcji ze stalowych rur pomiędzy którymi rozpięto sznurowaną siatkę po której dzieci mogą się wspinać w dowolny sposób. Jest to niezwykle proste rozwiązanie stwarzające jedynie pretekst do zabawy a sami użytkownicy używają elementów placu na swój, kreatywny sposób.

Ostatnią grupą są projekty wykorzystujące elementy służące do ćwiczeń. Przykładem takiego placu zabaw jest Potgieterstraat w Amsterdamie zaprojektowany przez Carve. ${ }^{6}$ Pomysł oparty na utworzeniu pofałdowanego terenu pokrytego powierzchnią z rozdrobnionej gumy w kolorze czarnym. W niektórych miejscach pofałdowany teren rozcięto wstawiając zjeżdżalnię w formie stalowej rynny w innych otwory w kształcie okręgów wyposażone zostały w trampoliny. Całość wpływa na rozwój fizyczny dzieci Również w projekcie Lazona Kawasaki Plaza w Kanagawie biuro projektowe Earthscape zaproponowało przestrzeń podzieloną na trójkąty ułożone pod różnym kątem w stosunku do powierzchni wejściowej na plac zabaw. Przestrzeń dedykowana jest zwłaszcza dla małych dzieci, które poprzez uchwyty wspinaczkowe na kolorowych trójkątach mogą rozwijać umiejętności fizyczne poprzez zabawę $w$ formie wspinaczki.

\section{Bibliografia}

[1] Playground Design, Michelle Galindo, Braun Publishing, 2012.

[2] Design for Healing Spaces, Therapeutic Gardens, Daniel WInterbottom, Amy Wagenfeld, Timber Pess, 2015.

[3] Metody Kreowania Tymczasowych Przestrzeni Publicznych, Natalia Przesmycka, TEKA KOMISJI ARCHITEKTURY, URBANISTYKI I STUDIÓW KRAJOBRAZOWYCH , Tom 4, 2015.

[4] Bezpieczny plac zabaw poradnik dla administratorów i właścicieli, David Yearly, Dominik Berlinski, Urząd Ochrony Komunikacji i Konsumentów, 2008.

[5] Ogrody Sensoryczne i Lecznicze, Wojciech Kocki, Bartłomiej Kwiatkowski, TEKA KOMISJI ARCHITEKTURY, URBANISTYKI I STUDIÓW KRAJOBRAZOWYCH , Tom 2, 2017. 